\title{
TET2 Gene Mutation
}

National Cancer Institute

\section{Source}

National Cancer Institute. TET2 Gene Mutation. NCI Thesaurus. Code C148283.

A change in the nucleotide sequence of the TET 2 gene. 